\title{
EUROPEAN CRIMINAL LAW AFTER BREXIT
}

\begin{abstract}
The victory for the 'Brexit' vote in the referendum last June has sent shockwaves around Europe. The initial shock has given way for some to the realisation of the legal and constitutional complexity of untangling the UK's relationship with the EU and re-engineering this relationship for a post-Brexit era, an era when the UK will be a third country for the EU. The legal challenges underpinning the reconfiguration of the UK's relationship with the EU are manifold, and, in many areas of EU law, they are interwoven with a series of practical and operational challenges. One of these areas is European criminal law, where post-Brexit complexity is compounded by ongoing constitutional complexity underpinning the UK's participation in the EU acquis while remaining an EU member state. Taking into account these complexities, this article will attempt to assess the future of European criminal law after Brexit. In order to do so, the article will focus on four main questions: what are the current constitutional complexities in the UK's participation in European criminal law (Sections I-III)? What will be the impact of Brexit on domestic criminal law and security in the UK (Section IV)? What are the possible legal avenues for EU-UK post-Brexit co-operation in the field of criminal law (Section V)? And what, if any, will be the impact of Brexit on the shaping and development of European criminal law in the future (Section VI)? By way of conclusion (Section VII), the article will attempt to synthesise the threads and common themes arising from the preceding sections, by emphasising the continuum of legal complexity from pre-to post-Brexit developments and casting light on the paradox of the UK's position after Brexit: if the UK wishes to continue participating in EU criminal law instruments and mechanisms, or to develop equivalent mechanisms of co-operation, the UK will have to comply with more EU instruments as a non-EU country compared to those it is bound by under its current status as an EU member state - ironically, ongoing links with the EU post-Brexit will spell the end of the UK's current 'pick-and-choose' approach to European integration in criminal matters.
\end{abstract}

* Professor of European Criminal Law, Head of the Department of Law, Dean for Research (Humanities and Social Sciences), Queen Mary University of London. The article builds upon and updates V Mitsilegas, 'The Uneasy Relationship between the UK and European Criminal Law. From Opt-outs to Brexit?' (2016) 63 Criminal Law Review 517-36. E-mail: v.mitsilegas@qmul.ac.uk. 


\section{THE CURRENT CONSTITUTIONAL POSITION: UK -OPT-OUTS' FROM POST-LISBON EU CRIMINAL LAW}

The entry into force of the Lisbon Treaty has led to efforts by the UK to extend the pre-Lisbon provisions enabling UK 'opt-outs' in the field of EU migration law to the field of EU criminal law adopted after the entry into force of the Lisbon Treaty. Protocol $21^{1}$ to the Lisbon Treaty extended the right of the UK not to participate in EU law to the whole of Title V Treaty on the Functioning of the European Union ("TFEU") on the Area of Freedom, Security and Justice, including criminal law measures. ${ }^{2}$ The right not to participate also extends to legislation amending existing measures which are binding upon the UK. The government decides on its participation in postLisbon measures on a case-by-case basis. ${ }^{3}$ In addition to these Protocols, the Lisbon Treaty has also introduced the legal possibility for the development of EU criminal justice à-la-carte, in the Treaty legal basis enabling the establishment of a European Public Prosecutor's Office ("EPPO"). ${ }^{4}$ Reflecting Member States' concerns over the impact of such an agency on national sovereignty and legal diversity, Art. 86 TFEU introduces an exception to the ordinary decisionmaking procedure by requiring the establishment of the Office by unanimity in the Council. However, if such unanimity is not forthcoming, the Treaty enables the establishment of enhanced cooperation with the participation of at least nine Member States. ${ }^{5}$ The UK has already announced its non-participation in the Regulation establishing the EPPO. ${ }^{6}$ The UK has a mixed record regarding par-

\footnotetext{
${ }^{1}$ Protocol 21 on the Position of the UK and Ireland in Respect of the Area of Freedom, Security and Justice, consolidated version in OJ EU C 202 of 7 June 2016, 295.

${ }^{2}$ Protocol 19 on the Schengen Acquis Integrated into the Framework of the EU, OJ EU C 326 of 26 October 2012, 290, covers the UK's participation regarding the Schengen acquis.

${ }^{3}$ See Art. 3 and 4 of Protocol 21.

${ }^{4}$ See also K Ambos and S Bock, 'Brexit and the European Criminal Justice System - An Introduction', supra in this issue, 4.5.

${ }^{5}$ Art. 86(1) TFEU.

${ }^{6}$ The European Union Act 2011 imposes a 'referendum lock' on the UK's participation on the EPPO-European Union Act 2011, cl 11, s 6 and in particular s 6(5)(c). See J R Spencer, 'The UK and EU Criminal Law: Should we be Leading, Following or Abstaining?', in V Mitsilegas, P Alldridge and L Cheliotis (eds),
} 
ticipation in post-Lisbon EU criminal law pursuant Protocol 21. ${ }^{7}$ In the field of mutual recognition, the UK has participated in the one major judicial cooperation instrument adopted after Lisbon, the Directive on the European Investigation Order ("EIO"). ${ }^{8}$ The UK participation in this Directive may be seen to have come against the odds in view of the increasingly Euro-sceptic political climate at Westminster but may be explained by the necessity to ensure that the UK remains in the first category of countries in an increasingly integrated system of judicial cooperation in the field of evidence. ${ }^{9}$ Less encouraging are the signs with regard to the UK participation in post-Lisbon EU criminal procedural law measures granting rights to individuals. While the UK has opted into the first measures adopted post-Lisbon on the rights of suspects and defendants in criminal procedure, it has not participated in a key instrument in the field, namely the Directive on the Right of Access to a Lawyer. ${ }^{10}$ The UK's non-participation in this measure may come as a surprise given the

\section{Footnote 6 continued}

Globalisation, Criminal Law and Criminal Justice. Theoretical, Comparative and Transnational Perspectives (Oxford, Hart Publishing, 2015) 135.

${ }^{7}$ For details see the regular annual reports by Ministry of Justice and Home Office, most recently: Ministry of Justice and Home Office, Fifth Annual Report to Parliament on the Application of Protocols 19 and 21 to the TEU and the TFEU ("the Treaties') in Relation to EU Justice and Home Affairs (JHA) matters (1 December 2013-30 November 2014): Cm 9006, February 2015, https://www.gov.uk/govern ment/uploads/system/uploads/attachment_data/file/401463/46831_Cm_9006_acces sible.pdf, last visited on 24 March 2017.

${ }^{8}$ Directive 2014/41/EU of the European Parliament and of the Council regarding the European Investigation Order in Criminal Matters, OJ EU L 130 of 1 May 2014, 1.

${ }^{9}$ House of Commons European Scrutiny Committee, The EIO and Parliamentary Scrutiny of Opt-in Decisions, Oral Evidence of Theresa May, HC 1416, Published on 15 September 2011, Q1: "what we found was that the police were saying to us that they felt the EIO would be of significant benefit to them. Indeed, there was a concern that, if we were not part of the EIO, what we would see was that the requests from the UK would, frankly, go to the bottom of the pile in future, in relation to assistance that they wanted from police forces in other Member States.'

${ }^{10}$ Directive 2013/48/EU of the European Parliament and of the Council on the Right of Access to a Lawyer in Criminal Proceedings and in European Arrest Warrant Proceedings, and on the Right to Have a Third Party Informed upon Deprivation of Liberty and to Communicate with Third Persons and with Consular Authorities while Deprived of Liberty, OJ EU L 294 of 6 November 2013,1; for a critique see D Giannoulopoulos, 'Fair Trial Rights in the UK Post Brexit: Out with the Charter and EU Law, in with the ECHR?' (2016) 7 New Journal of European Criminal Law 387 at 389. 
fact that the Directive introduces minimum standards which would arguably lead to minimum - if any - legislative changes to domestic criminal procedure. ${ }^{11}$ However, non-participation may be explained by the Government's reluctance to participate in a constitutionalised post-Lisbon framework where institutions such as the Commission and the Court of Justice ("CJEU") would have a say in evaluating the domestic implementation and proceeding to the interpretation of the terms of the Directive. ${ }^{12}$ Governmental concerns over the impact of participation in post-Lisbon EU criminal law in terms of the impact on domestic law in the light of judicial scrutiny by the CJEU also explains the latest tendency by the UK Government not to opt into the text of the Commission proposals, but rather to try to influence to the extent possible - negotiations and opt in post-adoption if the adopted measure appears to be acceptable to the UK. This is the strategy that the UK has followed in relation to measures including the Directive on Trafficking in Human Beings ${ }^{13}$ to which the UK has opted in post-adoption. ${ }^{14}$ This 'wait and see' strategy is increasingly coupled with a strategy attempting to broaden the field of the measures where the UK 'opt-out' applies. In the field of international

${ }^{11}$ Baroness Ludford has pointed out that UK concerns have been taken into account in negotiations: Oral evidence by Dominic Raab MP to the Justice SubCommittee of the House of Lords Select Committee on the European Union, Directive 2013/48/EU on the Right of Access to a Lawyer, Tuesday 19 January 2016, Q3.

12 The impact of the CJEU was a recurring theme in the Oral evidence by Dominic Raab MP to the Justice Sub-Committee of the House of Lords Select Committee on the European Union, Directive 2013/48/EU on the Right of Access to a Lawyer, Tuesday 19 January 2016, QQ 2,3 and 6. The Government's review of the Balance of Competences in the field of criminal justice included an extensive section on the potential impact of the CJEU in the field post-Lisbon-HM Government, Review of the Balance of Competences between the UK and the EU. Police and Criminal Justice, December 2014, para. 3.11-3.21.

${ }^{13}$ Directive 2011/36/EU of the European Parliament and of the Council on Preventing and Combating Trafficking in Human Beings and Protecting its Victims, and Peplacing Council Framework Decision 2002/629/JHA, OJ EU L 101 of 15 April 2011,1.

${ }^{14}$ See statement by Damian Green, Hansard, 9 May 2011, col. 977: 'we chose not to opt into the directive when it was initially put on the table last summer, because the draft text had to go through an extensive period of negotiation between the European Council and the European Parliament. We wanted to be absolutely sure that the text would not change during those negotiations in a way that would be detrimental to the integrity of the UK's criminal justice system. We wanted to consider a final text that had no risks attached and would not fundamentally change the UK's already strong position in the fight against human trafficking.' 
agreements, the UK has argued that Art. 1 and 2 of Protocol 21 'are not restricted to provisions in agreements concluded under a Title V legal base, but to those adopted or concluded 'pursuant to' Title V. ${ }^{, 15}$ Moreover, the UK has questioned the legal basis of measures adopted outside Title V TFEU but which are deemed to include a criminal law component (such as the recently adopted Fourth AntiMoney Laundering Directive ${ }^{16}$ ) and has resisted efforts to reclassify Title $\mathrm{V}$ measures as measures which could be adopted under different legal bases under the Treaty. The UK has challenged legal basis choices and has intervened in legal basis litigation before the Court of Justice with limited success. ${ }^{17}$ This litigious and 'wait-and-see' approach raises questions of compliance by the UK Government with the principle of loyal cooperation and prolongs - at times perhaps unnecessarily - the legal and political uncertainty regarding the commitment by the UK towards participating in key elements of the EU criminal justice system, elements which the UK has contributed decisively towards shaping. ${ }^{18}$

${ }^{15}$ House of Lords European Union Committee, The UK's Opt-In Protocol: Implications of the Government's Approach, 9th Report, Session 2014-15, HL Paper 136, para. 38 .

${ }^{16}$ Directive 2015/849/EU of the European Parliament and of the Council on the Prevention of the Use of the Financial System for the Purposes of Money Laundering or Terrorist Financing, Amending Regulation (EU) No 648/2012 of the European Parliament and of the Council, and Repealing Directive 2005/60/EC of the European Parliament and of the Council and Commission Directive 2006/70/EC, OJ EU L 141 of 5 June 2015, 73.

${ }^{17}$ See CJEU, UK v. Council of the European Union, No. C-431/11 (ECLI:EU:C:2013:589), Judgment (26 September 2013) (the EEA case); CJEU, European Commission v. Council of the European Union, No. C-137/12 (ECLI:EU:C:2013:675), Judgment (22 October 2013); CJEU, European Commission v. Council of the European Union, No. C-377/12 (ECLI:EU:C:2014:1903), Judgment (11 June 2014); CJEU, UK v. Council of the European Union, No. C-81/13 (ECLI:EU:C:2014:2449), Judgment (18 December 2014) (the Turkey case), critically analysed in House of Lords European Union Committee, The UK's Opt-In Protocol, above $\mathrm{n} 15$.

${ }^{18}$ The current 'wait-and-see' opt-in approach of the UK regarding the draft postLisbon Regulations on Eurojust and Europol are cases in point. See (Then) Parliamentary Under Secretary of State for Security (James Brokenshire), written statement to Parliament - government will conduct a thorough review of the final agreed text to inform active consideration of opting into the Eurojust Regulation post adoption: https:/www.gov.uk/government/speeches/european-commissionsproposals-on-eurojust-and-the-european-public-prosecutors-office, last visited on 23 March 2017. 


\section{UK PARTICIPATION IN THIRD PILLAR LAW: THE TRANSITIONAL PROVISIONS PROTOCOL}

UK concerns regarding the impact of the entry into force of the Lisbon Treaty on the transfer of sovereign powers to the EU in the field of criminal justice have resulted in a further political compromise, which addressed measures which had been adopted before the entry into force of the Lisbon Treaty, under the largely intergovernmental third pillar. Protocol No 36 on Transitional Provisions retained the pre-Lisbon limited powers of EU institutions with regard to third pillar law for a period of 5 years after the entry into force of the Lisbon Treaty. ${ }^{19}$ At least six months before the end of that period the UK could notify to the Council its non-acceptance of the full powers of the EU institutions in third pillar law. ${ }^{20}$ In case of a decision not to accept these powers, third pillar law ceases to apply to the $\mathrm{UK},{ }^{21}$ but the latter may notify subsequently its wish to participate in such legislation which has ceased to apply to it. ${ }^{22}$

This transitional period came to an end on 1 December 2014, a date that marked a significant step forward towards the constitutionalisation of EU criminal law by granting EU institutions their full powers of scrutiny with regard to third pillar law still in force after Lisbon. In addition to the enhanced powers of the Commission and the Court to monitor the implementation of third pillar law by Member States, a key constitutional change in this context is the normalisation of the Court's jurisdiction to give preliminary rulings. This impact is particularly visible in the case of the UK, which did not grant its judiciary the power to interact with the CJEU under the preliminary ruling procedure under the third pillar. The limits of the involvement of the UK judiciary can be seen in case-law concerning the interpretation of key concepts in the field of judicial cooperation in criminal matters, and in particular mutual recognition, including the concept of 'judicial authority'. The Supreme Court of the UK, which has not been granted the right to send preliminary references to

19 Art. 10(1) and 10(3) of Protocol 36 on Transitional Provisions, OJ EU C 115 of 8 May 2008, 322; for a background to the transitional provisions see A Hinarejos, J R Spencer and S Peers, Opting out of EU Criminal Law: What Is Actually Involved?, CELS Working Paper, New Series, vol.1, University of Cambridge Faculty of Law, September 2012.

${ }^{20}$ Art. 10(4).
${ }^{21}$ Art. 10(4).
${ }^{22}$ Art. 10(5). 
Luxembourg by the UK Government under the third pillar arrangements, has had to grapple with the question of the definition of judicial authority for the purposes of the Framework Decision ("FD") on the European Arrest Warrant ("EAW") in two recent cases, the case of Assange ${ }^{23}$ and the case of Bucnys. ${ }^{24}$ In the absence of the cooperative avenue of preliminary references with regard to third pillar law for UK courts, the Supreme Court could not avail of the assistance of the CJEU and thus had to develop an autonomous concept of judicial authority on its own. In Bucnys, the Court did so largely by reference to what it assumed Luxembourg would decide on this matter. Subsequently, the CJEU put forward a definition of the concept of judicial authority for the purposes of the FD on Mutual Recognition of Financial Penalties in the case of Baláz. ${ }^{25}$ The normalisation of the preliminary references jurisdiction of the CJEU after the end of the transitional period will be a considerable improvement in enabling national courts in all Member States, including UK courts, to send questions on the interpretation of third pillar law to Luxembourg and thus contribute decisively to legal certainty and the cooperative evolution of the EU acquis in the field.

It is important to pay attention to the decisions made by the UK Government after the expiry of the five year deadline set out in the Transitional Provisions Protocol. ${ }^{26}$ The UK notified the Presidency of the EU that, pursuant to Art. 10(4) of Protocol 36, it did not accept the powers of the EU institutions; accordingly, third pillar law would cease to apply in the UK from 1 December $2014 .{ }^{27}$ However, the UK eventually indicated that it would seek to opt back into 35 of third pillar measures including the FD EAW. ${ }^{28}$ The five-year tran-

${ }^{23}$ [2012] UKSC 22.

24 [2-13] UKSC 71.

${ }^{25}$ CJEU, Proceedings concerning the enforcement of a financial penalty issued against Marián Baláž, No. C-60/12 (ECLI:EU:C:2013:733), Judgment (14 November 2013).

${ }^{26}$ For an analysis see V Mitsilegas, S Carrera and $\mathrm{K}$ Eisele, The End of the Transitional Period for Police and Criminal Justice Measures Adopted before the Lisbon Treaty. Who Monitors Trust in the European Justice Area?, CEPS Paper in Liberty and Security in Europe, no. 74, Centre for European Policy Studies, Brussels, December 2014.

${ }^{27}$ Council Document 12750/13, UK notification according to Art. 10(4) of Protocol No 36 to TEU and TFEU, 26 July 2013.

${ }^{28}$ Council Framework Decision 2002/584/JHA on the European Arrest Warrant and the Surrender Procedures between Member States, OJ EU L 190 of 18 July 2002,1 . 
sitional period expired at the 31 November 2014 and the continuation of the applicability of these 35 measures to the UK has been confirmed. Third pillar law will continue to apply to the UK vis-à-vis the vast majority of measures applying the principle of mutual recognition in criminal matters (including the FD EAW) and a number of other key measures including legislation establishing Europol and Eurojust and legislation on joint investigation teams and criminal records. ${ }^{29}$ Third pillar law which has ceased to apply to the UK following the expiry of the transitional period includes inter alia a number of measures on substantive criminal law, the FD on prevention and settlement of conflicts of jurisdiction, and the FD on the mutual recognition of probation decisions. ${ }^{30}$ As was the case with the UK's decision to participate in the post-Lisbon Directive on the EIO, the 'opting-back-into' the FD EAW was supported by a number of relevant stakeholders and practitioners in the field of criminal justice. ${ }^{31}$ Similarly, views of law enforcement practitioners were taken into account by the UK Government in its subsequent decision for the UK to opt back into a series of measures related to the Prüm system of storage and exchange of personal data, including DNA data. ${ }^{32}$ In her speech before the House of Commons, the Home Secretary stressed the views of senior law enforcement officers and stated that attempts to exchange data in other ways would require not only an intergovernmental agreements, but the building of separate systems. ${ }^{33}$ The UK Government has thus opted back into the

\footnotetext{
${ }^{29}$ See Annex to Decision 2014/836/EU, [2014], OJ EU L 343 of 28 November 2014, 11.

${ }^{30}$ Notice 430/03, [2014] OJ EU C 430 of 1 December 2014, 17.

${ }^{31}$ House of Commons Home Affairs Committee, Pre-Lisbon Treaty EU police and criminal justice measures: the UK's opt-in decision, $9^{\text {th }}$ Report, Session 2013-14, HC 615, para. 8-12. See also T May, 'Fight Europe by all means, but not over this Arrest Warrant', Daily Telegraph, 9 November 2014, http:/www.telegraph.co.uk/news/ politics/conservative/11216589/Theresa-May-Fight-Europe-by-all-means-but-notover-this-Arrest-Warrant.html, last visited on 21 March 2017.

32 Council Decision 2008/615/JHA on the Stepping up of Cross-Border Cooperation, Particularly in Combating Terrorism and Cross-Border Crime, OJ EU L 210 of 6 August 2008, 1; Council Decision 2008/616/JHA on the Implementation of Decision 2008/615/JHA on the Stepping up of Cross-Border Cooperation, Particularly in Combating Terrorism and Cross-Border Crime, OJ EU L 210 of 6 August 2008, 12; Council Framework Decision 2009/905/JHA on Accreditation of Forensic Service Providers Carrying out Laboratory Activities, OJ EU L 322 of 9 December 2009, 14.

${ }^{33}$ House of Commons Hansard Debates for 8 December 2015: T May- cl. 914, 916 respectively.
} 
vast majority of the key third pillar law enforcement measures after the expiry of the Transitional Provisions Protocol deadline.

\section{THE CHALLENGES OF THE UK'S-PICK- AND-CHOOSE' APPROACH}

The article has thus far outlined a complex legal framework aiming to give the appearance of insulating the UK from any advances in the field of EU criminal law which are deemed unwanted or unnecessary by the UK Government by allowing the UK not to participate in EU criminal justice measures. While this stance may reap short-term political gains, the current position of the UK based on a 'pick-andchoose' model of differentiated integration in criminal matters becomes increasingly untenable in an interdependent and increasingly integrated Union area of criminal justice after Lisbon. The varied landscape with regard to the participation of the UK in EU criminal law measures post-Lisbon poses significant challenges for legal certainty, coherence and the protection of fundamental rights in Europe's area of criminal justice. These challenges become more complex following the end of the transitional period in Protocol 36 and can be fully appreciated when examining the UK's position with regard to the operation of the key mutual recognition instrument, the FD EAW. As seen above, the UK has chosen to participate fully in the FD EAW, without participating at the same time in a key measure on the rights of suspects and accused persons in criminal proceedings, the Directive on Access to a Lawyer. The selective participation of the UK in this context is problematic not only from the perspective of the protection of fundamental rights, but also from the perspective of the coherence of EU law. ${ }^{34}$ The legal basis for the Directive on the Right of Access to a Lawyer (as with the other Directives implementing the Stockholm Roadmap ${ }^{35}$ ) is Art. 82(2) TFEU. This provision grants for the first time express competence to the EU to legislate on aspects of criminal procedure (including explicitly the rights of the defence) where necessary to facilitate the operation of the principle of mutual recognition in criminal matters. The legality of post-Lisbon legislation on defence rights, including the Directive

\footnotetext{
${ }^{34}$ Mitsilegas, Carrera and Eisele, 'The End of the Transitional Period for Police and Criminal Justice Measures Adopted before the Lisbon Treaty' above n 26.

${ }^{35} \mathrm{Cf}$. Ambos and Bock 'Brexit and the European Criminal Justice System - An Introduction', above $\mathrm{n} 4$ at 3.3.
} 
on the Right of Access to a Lawyer, is thus inextricably linked with the effective operation of mutual recognition in criminal matters, including with regard to the FD EAW. This link is confirmed in the Preamble of the Directive 2013/48/EU on the Right of Access to a Lawyer itself. The non-participation of the UK in measures on procedural rights, including the Directive on the Right of Access to a Lawyer, undermines the effective operation of the FD EAW as far as the UK is concerned. ${ }^{36}$ There is a direct causal link under EU constitutional law between the adoption of EU defence rights measures under Art. 82(2) TFEU and the effective operation of mutual recognition in criminal matters. The non-participation of the UK in such measures poses fundamental challenges with regard to compliance by the UK with the fundamental rights obligations incumbent upon EU Member States participating in the system of mutual recognition in criminal matters. The UK's nonparticipation also challenges the coherence of EU criminal law in an integrated Area of Freedom, Security and Justice where EU criminal law measures are increasingly interconnected.

It could be argued that from a black letter perspective the current position of the UK is tenable: after all, under the Lisbon Treaty the UK can opt-into (or opt out from) any post-Lisbon legislative proposal in the field of criminal justice on a case-by-case basis (and has decided not to participate in the access to a lawyer Directive). However, this argument runs counter to a teleological approach which respects fully the objectives and the integrated nature of the Area of Freedom, Security and Justice. There are important precedents by the CJEU in that respect in cases involving UK requests to participate in measures related to border controls. A key ruling in this context concerns the UK request to participate in a third pillar Decision (Decision 2008/633) authorising access to the Visa Information System ("VIS") by law enforcement authorities. ${ }^{37}$ The Decision is a third pillar measure (and at the time the Treaties did not include a Protocol extending the UK's opt-out arrangements to the third pillar). In applying for annulment of Decision 2008/633, the UK submitted that that decision does not constitute a development of provisions of the Schengen acquis in which the UK did not take part, but a police cooperation measure, as is also apparent from the Council's choice of legal basis, namely Art. 30(1)(b) EU and 34(c)(2)

\footnotetext{
${ }^{36}$ See for further analysis V Mitsilegas, EU Criminal Law After Lisbon (Oxford, Hart Publishing, 2016) Chap. 6.

${ }^{37}$ CJEU, UK v. Council of the European Union, No. C-482/08 (ECLI:EU:C:2010:631), Judgment (26 October 2010).
} 
EU. ${ }^{38}$ The Court however ruled against UK participation in the Decision. According to the Court, when classifying a measure as falling within an area of the Schengen acquis, and the need - where that acquis evolves - to maintain that coherence, must be taken into account. ${ }^{39}$ The Court added that the cooperation established by Decision 2008/633 could not, from both a functional and a practical point of view, exist independently of the VIS which falls, like Decision 2004/512 and the VIS Regulation on which the VIS is based, within the scope of the Schengen acquis concerning the common visa policy. ${ }^{40}$ The Court adopted a teleological and contextual approach focusing on the coherence of the Schengen acquis, following largely precedents in earlier rulings excluding the UK participation in the Frontex and biometrics Regulations. ${ }^{41}$ The Court's rulings are also applicable with regard to the UK participation in EU criminal law measures. The legality of the adoption of procedural rights measures under Art. 82(2) TFEU is inextricably linked with the effective operation of mutual recognition measures. As the Treaty is currently worded, defence rights measures under Art. 82(2) TFEU cannot exist independently of measures on mutual recognition, including the FD EAW. Participating in the enforcement measures but not in the measures granting rights in order to facilitate judicial cooperation challenges the coherence of Europe's area of criminal justice and is contrary to EU law.

\section{THE IMPACT OF BREXIT ON DOMESTIC CRIMINAL JUSTICE AND SECURITY}

If the current legal landscape regarding the UK's participation in EU criminal law leaves much to be desired in terms of effectiveness, coherence and legal certainty, the situation will become even more challenging following a Brexit. The aim of this section is to highlight key areas of EU criminal law currently in force from which the UK will be excluded post-Brexit in the fields of judicial co-operation in

\footnotetext{
${ }^{38}$ Ibid at para. 30 .

${ }^{39}$ Ibid at para. 48.

${ }^{40}$ Ibid at para. 54.

${ }^{41}$ CJEU, UK v. Council of the European Union, No C-77/05 (ECLI:EU:C:2007:803), Judgment (18 December 2007) (Frontex), para. 55; CJEU, UK v. Council of the European Union, No. C-137/05 (ECLI:EU:C:2007:805), Judgment (18 December 2007) (biometrics).
} 
criminal matters, of police co-operation and surveillance, and of the operation of EU criminal justice bodies and agencies. The next section will flesh out potential legal avenues of co-operation between the UK and the EU and its Member States and demonstrate the limits of such avenues to provide a level of co-operation in criminal matters which is equivalent to that of a state enjoying full EU membership.

\subsection{Judicial Co-operation in Criminal Matters: Mutual Recognition}

Judicial co-operation has been the motor of European integration in criminal matters, most notably by the application of the principle of mutual recognition in the field. ${ }^{42}$ This sub-section will focus on three key measures in the field of judicial co-operation; the pre-Lisbon FD EAW and the post-Lisbon Directive on the EIO, applying the principle of mutual recognition in the fields of surrender and evidence respectively; and measures establishing EU-wide co-operation in terms of exchange of criminal record information. The tangible benefits of these measures for intra-EU co-operation will be demonstrated, and the improvements in the EU legal framework - in particular regarding the protection of fundamental rights - will be highlighted.

\subsubsection{The European Arrest Warrant}

The FD EAW ${ }^{43}$ is the most emblematic and most widely implemented EU criminal law instrument. It aims to compensate for the freedom of movement enabled by the abolition of internal borders by ensuring that Member States' justice systems can reach extraterritorially in order to bring individuals who have taken advantage of the abolition of borders to flee the jurisdiction to face justice. The FD applies the principle of mutual recognition in the field of criminal law and has established a system which requires the recognition of EAWs and the surrender of individuals wanted for prosecution or to serve a custodial sentence with a minimum of formality, automaticity, and speed. ${ }^{44}$ A key innovation introduced is the in principle abolition of the non-extradition of own nationals. Mutual recognition is based on

\footnotetext{
${ }^{42}$ On the application of the principle of mutual recognition in criminal matters, see V Mitsilegas, EU Criminal Law (Oxford, Hart Publishing, 2009) Chap. 3.

${ }^{43}$ Cf. above n 28; thereto K Ambos, European Criminal Law (Cambridge, CUP, 2017) Chap. IV mn. 43 ff.; also Ambos and Bock 'Brexit and the European Criminal Justice System - An Introduction', above n 4 at 3.4.1.

${ }^{44} \mathrm{~V}$ Mitsilegas, 'The Constitutional Implications of Mutual Recognition in Criminal Matters in the EU' (2006) 43 Common Market Law Review 1277.
} 
mutual trust, premised on the presumption that EU Member States are in principle human rights compliant. This presumption of trust has been recently highlighted by the CJEU in its Opinion 2/13 on the accession of the EU to the ECHR, where the Court elevated mutual trust into a principle of fundamental importance in EU law. ${ }^{45}$ Yet critics of the EAW system and the automaticity it has introduced have rightly pointed out that the presumption of trust is not always justified, with human rights violations being ascertained across EU Member States by the Strasbourg Court on a regular basis. A key question related to the legitimacy of the EAW system is whether the system can operate on the basis of blind trust, or whether national authorities have leeway to examine the consequences of executing warrants for the human rights of the requested persons.

EU law has dealt with the human rights concerns arising from the operation of the EAW system in three main ways: by allowing national authorities to consider refusing to execute warrants if there are concerns that execution would result in human rights breaches; by introducing a test of proportionality in the operation of the EAW system; and by legislating for human rights, namely adopting legally binding instruments harmonising defence rights legislation and aiming to facilitate the operation of mutual recognition. ${ }^{46}$ In terms of taking into account of human rights by the executing authorities, it is noteworthy that - with the exception of a general human rights clause $^{47}$ - the operative provisions of the Framework Decision do not include a ground of refusal to execute a EAW on human rights grounds. However, a number of EU Member States, including the UK in the Extradition Act 2003, have 'goldplated' transposition by expressly including human rights grounds for refusal in national implementing law. Significantly, the CJEU has recently confirmed that execution may be refused on human rights grounds. In Joint Cases Aranyosi and Căldăraru, ${ }^{48}$ the Court found that

${ }^{45}$ CJEU, Case Opinion 2/13 of 18 December 2014 pursuant to Article 218(11) TFEU (ECLI:EU:C:2014:2454), para. 191; for a critical analysis with further references Ambos, European Criminal Law, above n 44 at Chap. II mn. 9-10.

${ }^{46}$ V Mitsilegas, 'Mutual Recognition, Mutual Trust and Fundamental Rights After Lisbon', in V Mitsilegas, M Bergström and T Konstadinides (eds), Research Handbook on EU Criminal Law (Cheltenham, Edward Elgar 2016) 148.

47 Art. 1(3).

${ }^{48}$ CJEU, Pál Aranyosi and Robert Căldăraru v. Generalstaatsanwaltschaft Bremen, No. C-404/15 and C-659/15 PPU (ECLI:EU:C:2016:198), Judgment (5 April 2016). 
'where there is objective, reliable, specific and properly updated evidence with respect to detention conditions in the issuing Member State that demonstrates that there are deficiencies, which may be systemic or generalised, or which may affect certain groups of people, or which may affect certain places of detention, the executing judicial authority must determine, specifically and precisely, whether there are substantial grounds to believe that the individual concerned by a European arrest warrant, issued for the purposes of conducting a criminal prosecution or executing a custodial sentence, will be exposed, because of the conditions for his detention in the issuing Member State, to a real risk of inhuman or degrading treatment, within the meaning of Article 4 of the Charter, in the event of his surrender to that Member State. To that end, the executing judicial authority must request that supplementary information be provided by the issuing judicial authority, which, after seeking, if necessary, the assistance of the central authority or one of the central authorities of the issuing Member State, under Article 7 of the Framework Decision, must send that information within the time limit specified in the request. The executing judicial authority must postpone its decision on the surrender of the individual concerned until it obtains the supplementary information that allows it to discount the existence of such a risk. If the existence of that risk cannot be discounted within a reasonable time, the executing judicial authority must decide whether the surrender procedure should be brought to an end. ${ }^{49}$

The Court's ruling is significant not only in affirming for the first time that execution of a Warrant may be refused in certain circumstances, but also in negating a system of mutual recognition based on automaticity and blind trust: human rights compliance must be queried and ascertained on the ground, and on the basis of concrete evidence. In addition to these safeguards, the EAW system must operate in compliance with the principle of proportionality. The need to address these proportionality concerns was acknowledged by the European Commission in its latest EAW implementation report. ${ }^{50}$ The prevailing view has thus far being for proportionality to be dealt with in the issuing and not in the executing Member State. This is the interpretative guidance given in the revised version of the European Handbook on the EAW. ${ }^{51}$ A step further with regard to the treatment of proportionality as a limit to mutual recognition has been

\footnotetext{
${ }^{49}$ Ibid at para. 104 (emphasis added).

${ }^{50}$ Report from the Commission to the European Parliament and the Council on the implementation since 2007 of the Council Framework Decision of 13 June 2002 on the European Arrest Warrant and the surrender procedures between Member States $\operatorname{COM}(2011) 175$ final, Brussels, 11.4.2011, 8. See also Ambos, European Criminal Law, above $\mathrm{n} 44$ at Chap. IV mn. 71-2 (re EAW), 90 (re EIO).

${ }^{51}$ Council Document 17195/1/10 REV 1, Revised version of the European handbook on how to issue a European Arrest Warrant, 17. December 2010.
} 
taken in the UK, which in its latest version of the EAW implementing legislation (the Extradition Act 2003) has treated non-compliance with proportionality as a ground of refusal to execute a Warrant (and not merely as a requirement to be checked in the issuing state) ${ }^{52}$ The amended provisions provide for an exhaustive list of matters to be taken into account by the judge when ruling on proportionality ${ }^{53}$ and thus far English judges have interpreted these matters restrictively. ${ }^{54}$ A Brexit will have the consequence of the UK - which has been pioneering in introducing human rights safeguards in the EAW - will leave the system at the very time when EU institutions appear to have begun to take these very human rights considerations seriously.

\subsubsection{The European Investigation Order}

The EIO Directive ${ }^{55}$ regulates the exchange of evidence between EU Member States in the field of criminal justice. The Directive applies the principle of mutual recognition in the field of evidence, and is the first major instrument on mutual recognition adopted after the entry into force of the Lisbon Treaty. The Directive is of major importance with regard to its applicability, as it will replace, as of 22 May 2017, the corresponding provisions applicable between Member States bound by it of the Council of Europe ("CoE") Mutual Legal Assistance and its protocols, the Convention implementing the Schengen Agreement and the EU Mutual Legal Assistance Convention and its Protocol. ${ }^{56}$ The Directive will also replace the FD on the European Evidence Warrant $(\text { "EEW") })^{57}$ and the relevant provisions of the FD on the Mutual

${ }^{52}$ Section 157 of the Anti-Social Behaviour, Crime and Policing Act 2014 has amended Section 21A of the Extradition Act 2003 to treat lack of proportionality as a ground for refusal (section 21A(1)(b)).

${ }^{53}$ Section $21 \mathrm{~A}(2)$. These matters are: the seriousness of the conduct alleged to constitute the extradition offence; the likely penalty that would be imposed if the individual was found guilty of the extradition offence; and the possibility of the relevant foreign authorities taking measures that would be less coercive than the extradition sought (section 21(A)(3)).

${ }^{54}$ See Miraszewski v. Poland [2014] EWCH 4261 (Admin); Celinski v. Poland [2015] EWHC 1274 (Admin).

${ }^{55}$ Cf. above n 8; thereto Ambos, European Criminal Law, above n 44 at Chap. IV mn. $88 \mathrm{ff}$.; also Ambos and Bock 'Brexit and the European Criminal Justice System An Introduction', above $\mathrm{n} 4$ at 3.4.2.

${ }^{56}$ Art. 34(1).

${ }^{57}$ Council Framework Decision 2008/978/JHA on the European Evidence Warrant for the Purpose of Obtaining Objects, Documents and Data for Use in Proceedings in Criminal Matters, OJ EU L 350 of 30 December 2008, 72. 
Recognition of Freezing Orders. ${ }^{58}$ In this manner, the EIO Directive will become the sole legal instrument regulating the exchange of evidence and mutual legal assistance between EU Member States. 22 May 2017 is also the transposition deadline for Member States. ${ }^{59}$ This will mean in practice that judicial co-operation in the key field of evidence for Member States parties to the EIO will take place speedily and as a matter of priority in relation to requests by third countries.

Following on from on-going concerns regarding the potential adverse human rights implications of automatic mutual recognition, the EIO Directive has introduced a number of provisions aiming to protect human rights and avoid arbitrary and unlawful use of the system. The Directive expressly includes non-compliance with fundamental rights as a ground for refusal to recognise and execute an EIO ${ }^{60}$ with the Preamble also stating that the presumption of compliance of Member States with human rights is rebuttable. ${ }^{61}$ The Directive has also introduced a proportionality check in the issuing state stating that the issuing authority may only issue an EIO where the issuing of the latter is necessary and proportionate and where the investigative measures indicated in the EIO could have been ordered under the same conditions in a similar domestic case. ${ }^{62}$ Moreover, the Directive contains provisions aiming to curb arbitrary or unlawful action by the issuing and the executing authorities. The executing authority may refuse to recognise and execute a EIO when the latter has been issued in proceedings brought by administrative or judicial authorities referred to in Art. 4(b) and (c) of the Directive and the investigative measure would not be authorised under the law of the executing State in a similar domestic case. ${ }^{63}$ On the other hand, the issuing authority may only issue a EIO where the investigative measures indicated therein could have been ordered under the same conditions in a similar domestic case. ${ }^{64}$ This provision has been in-

${ }^{58}$ Council Framework Decision 2003/577/JHA on the Execution in the EU of Orders Freezing Property or Evidence, OJ EU L196 of 2 August 2003, 45, Art. 34(2).

59 Art. 36(1).

${ }^{60}$ Art. 11 - optional grounds for non-recognition or non-execution: 11(1)(f): where there are substantial grounds to believe that the execution of the investigative measure indicated in the EIO would be incompatible with the executing State's obligations in accordance with Art. 6 TEU and the Charter.

${ }^{61}$ Preamble, recital 19. Emphasis added.

${ }^{62}$ Art. 6(1)(a) and (b) respectively.

${ }^{63}$ Art. 11(1)(c).

${ }^{64}$ Art. 6(1)(b). 
cluded to avoid instances where Member States use the EIO to 'fish' for evidence and obtain evidence abroad which they are not able to obtain under their own domestic legal and constitutional procedures. Brexit would mean that the UK would be excluded by a system of cooperation underpinned by both efficiency and a high level of human rights protection and from an instrument participation in which has been strongly advocated by UK practitioners.

\subsection{Information Systems: From SIS II to ECRIS}

An adverse security consequence of Brexit would be the withdrawal of the UK from a series of EU information systems and databases which contribute to the EU criminal justice architecture. A key plank of this system is participation in the police aspects of the second generation Schengen Information System (SIS II), to which the UK has heavily invested in and which is closely linked with the effective operation of the EAW via the insertion of SIS alerts. ${ }^{65}$ However, Brexit may mean the UK's exclusion from another significant mechanism of co-operation on the basis of the establishment of communication avenues at EU level, namely in the field of exchange of criminal records. EU law has developed an extensive mechanism of exchange of information on criminal records of EU citizens, which should enable national authorities to have a full picture of the criminal record status of EU citizens who enter their territory. There are two main elements of the EU-wide system of exchange of criminal records. FD 2009/315/JHA on the Organisation and Content of the Exchange of Information Extracted from the Criminal Record between Member States ${ }^{66}$ calls for the establishment of a central authority for managing criminal records in each Member State ${ }^{67}$ and places the central authority of the convicting Member State under the obligation to inform as soon as possible the central authorities of other member states of any convictions handed down within its territory against the nationals of such other Member States, as entered in the

\footnotetext{
${ }^{65}$ On the importance of the SIS II in this context see House of Lords European Union Committee, Brexit: future UK-EU security and police cooperation, 7th Report, session 2016-2017, para. 89; on SIS and SIS II also Ambos, European Criminal Law, above $\mathrm{n} 44$ at Chap. IV mn. 26, 28.

${ }^{66}$ Council Framework Decision 2009/315/JHA on the Organisation and Content of the Exchange of Information Extracted from the Criminal Record between Member States OJ EU L 93 of 7 April 2009, 23.

${ }^{67}$ Art. 3.
} 
criminal record. ${ }^{68}$ Information provided includes information on the nature of the criminal conviction, the offence giving rise to the conviction and the contents of the conviction. ${ }^{69}$ A parallel Decision on the Establishment of the European Criminal Records Information System ("ECRIS") ${ }^{70}$ establishes ECRIS as a decentralised information technology system based on the criminal records databases in each Member State composed of an interconnection software enabling the exchange of information between Member States criminal records databases and a common communication infrastructure that provides an encrypted network. ${ }^{71}$ These legislative instruments have provided a solid EU-wide mechanism of exchange of criminal records, which according to the Commission has led to significant progress in improving the exchange of criminal records information within the Union. ${ }^{72}$ This view is shared by the UK Government, which has noted that the EU system "has allowed the police to build a fuller picture of offending by UK nationals and allowed the courts to be aware of the previous offending of EU nationals being prosecuted. The previous conviction information can be used for bail, bad character and sentencing, as well as by the prison and probation service when dealing with the offender once sentenced. ${ }^{, 73}$ After the Paris attacks, the Commission has proposed legislation extending the exchange of criminal records to third-country nationals, ${ }^{74}$ a move which the UK Government seems to support in principle. ${ }^{75}$ Brexit would mean

${ }^{68}$ Art. 4(2).

${ }^{69}$ Art. 11 (1).

${ }^{70}$ Council Decision 2009/316/JHA on the Establishment of the European Criminal Records Information System (ECRIS) in Application of Article 11 of Framework Decision 2009/315/JHA, OJ EU L 93 of 7 April 2009, 33.

71 Art. 3(2).

${ }^{72}$ European Commission, Report on the implementation of Council Framework Decision 2009/315/JHA of 26 February 2009 on the organisation and content of the exchange of information extracted from criminal record between Member States, COM (2016) 6 final, 19 January 2016.

${ }^{73}$ Command Paper (8671) cited in House of Commons European Scrutiny Committee, Exchanging Information on Criminal Convictions, 2 March 2016, para. 10.11, http://www.publications.parliament.uk/pa/cm201516/cmselect/cmeuleg/342xxiii/34213.htm, last visited on 21 March 2017.

${ }^{74}$ Proposal for a Directive amending Council Framework Decision 2009/315/JHA as Regards the Exchange of Information on Third Country Nationals and as Regards the European Criminal Records Information System (ECRIS), and replacing Council Decision 2009/316/JHA, COM (2016) 7 final.

${ }^{75}$ House of Commons European Scrutiny Committee, above n 73. 
that the UK would not be at the forefront of developments in this field, which may provide crucial information for the protection of public safety in the country. Withdrawal from these systems would entail a significant security and financial cost for the UK, while maintaining an ongoing connection with systems established under EU law will entail, as will be mentioned in the sub-sections below, compliance by the UK with EU privacy and data protection law requirements.

\subsection{Surveillance and Police Co-operation}

Another consequence of Brexit would be to exclude the UK from the development of sophisticated - and far-reaching - legal frameworks enabling the collection and exchange of a wide range of personal data for law enforcement purposes. The Prüm measures analysed earlier in the article constitute key examples of innovation (or, arguably, widening and deepening the web of surveillance) by facilitating the collection and exchange of DNA data. Another form of police and judicial co-operation from which the UK may be excluded post-Brexit is the establishment of joint investigation teams ("JITs"), ${ }^{76}$ to which UK officers currently participate extensively. ${ }^{77}$ The capacity to act at a multilateral, transnational level has been highlighted as a key advantage of JITs. ${ }^{78}$ In addition to this 'public' form of surveillance, the EU has innovated by promoting public/private partnerships in the field of policing and surveillance. After the Paris attacks, the focus in this context has been on the surveillance of mobility, with EU institutions having recently agreed upon a Directive Establishing an EU Passenger Name Records ("PNR") Transfer System. ${ }^{79}$ It introduces an PNR system for flights flying into the EU, with Member States being given the option to apply it also to intra-EU flights. The Directive has been welcomed by UK security professionals as a significant step towards

\footnotetext{
${ }^{76}$ For the principal legal framework, see Council Framework Decision 2002/465/ JHA on Joint Investigation Teams, OJ EU L 162 of 20 June 2002, 1.

${ }^{77}$ According to the Director of Public Prosecutions Alison Saunders, "we get a lot out of joint investigation teams because they help us to make sure that we collect the right evidence. It is much quicker than doing individual letters of request because you collect it all together and it is there; it helps with issues around jurisdiction. It helps with disclosure issues.' - evidence to House of Lords EU Committee, Q 54.

${ }^{78}$ See House of Lords European Union Committee, Brexit: future UK-EU security and police cooperation, above $\mathrm{n} 65$ at paras 74 and 75 .

${ }^{79}$ Directive 2016/681/EU of the European Parliament and of the Council on the Use of Passenger Name Record (PNR) Data for the Prevention, Detection, Investigation and Prosecution of Terrorist Offences and Serious Crime, OJ EU L 119 of 4 May 2016, 132.
} 
the security of the EU and the UK. ${ }^{80}$ A further aspect of public/private partnership in the field of the collection and exchange of personal data involves financial data surveillance. The recently adopted Fourth EU Money Laundering Directive calls for the intensification of information exchange and collaboration between national financial intelligence units ("FIUs"). ${ }^{81}$ The Directive requires Member States to ensure that FIUs cooperate with each other 'to the greatest extent possible' irrespective of the model they have chosen for their organisation, ${ }^{82}$ while FIUs are empowered to exchange, spontaneously or upon request, any information that may be relevant for the processing or analysis of information by the FIU related to money laundering or terrorist financing, 'even if the type of predicate offence that may be at stake is not identified at the time of the exchange'. ${ }^{83}$

The impact of Brexit on police co-operation and surveillance capacity may be considerable. In this context, the entry into force of the Lisbon Treaty has made it clearer that EU action on policing and surveillance must be compatible with the EU Charter of Fundamental Rights ("Charter"), the ECHR and secondary EU law on data protection. Already both the Strasbourg and Luxembourg Courts have sent strong signals limiting state power in the field. In the case of $S$. and Marper, ${ }^{84}$ the Strasbourg Court has placed considerable limits on the power of the state to retain sensitive personal data without charge, while in the cases of Digital Rights Ireland ${ }^{85}$ and

80 'The EU can't dictate to us on security but staying in it can keep us safer' Jonathan Evans and John Sawers (former heads of MI5 and MI6 respectively), The Sunday Times, 8 May 2016.

${ }^{81}$ Directive 2015/849/EU of the European Parliament and of the Council on the Prevention of the Use of the Financial System for the Purposes of Money Laundering or Terrorist Financing, Amending Regulation (EU) No 648/2012 of the European Parliament and of the Council, and Repealing Directive 2005/60/EC of the European Parliament and of the Council and Commission Directive 2006/70/EC, OJ EU L 141 of 5 June 2015, 73.

${ }^{82}$ Art. 52.

${ }^{83}$ Art. 53(1); for an analysis, see V Mitsilegas and N Vavoula, 'The Evolving European Union Anti-Money Laundering Regime: Challenges for Fundamental Rights and the Rule of Law' in Maastricht Journal of European and Comparative Law, forthcoming.

${ }^{84}$ ECtHR, S. and Marper v. UK, Applications nos. 30562/04 and 30566/04, Judgment (4 December 2008).

${ }^{85}$ CJEU, Digital Rights Ireland Ltd v. Minister for Communications, Marine and Natural Resources and Others and Kärntner Landesregierung and Others, No. C-293/12 and C-594/12 (ECLI:EU:C:2014:238), Judgment (8 April 2014). 
Schrems ${ }^{86}$ the Luxembourg Court has placed clear limits on mass surveillance in cases involving personal data generated by the private sector. In this light, Brexit may for some be a welcome development in 'liberating' the UK executive from the requirement to comply with the Charter. Indeed, the UK can introduce domestic law mirroring and going beyond - EU developments in the field. However, Brexit will have the concrete consequence of the UK being excluded from the EU co-operative mechanisms on policing and surveillance (whether these are speedy DNA exchanges under Prüm or suspicious transaction reports from FIU to FIU), in particular if the UK does not comply with EU human rights benchmarks. ${ }^{87}$

\section{PARTICIPATION IN EU CRIMINAL JUSTICE BODIES AND AGENCIES}

While even within the framework of its current EU membership the UK has stated that it will not participate in the Regulation establishing a EPPO, the question of the impact of Brexit on the UK's cooperation with the two other key EU bodies in the field of criminal justice, Europol ${ }^{88}$ and Eurojust, ${ }^{89}$ remains open. The establishment of both Europol and Eurojust has been innovative, with the powers, tasks and mandate of these bodies being in constant evolution. ${ }^{90}$ Europol has developed in an important source of criminal intelligence for Member States, while the value of Eurojust lies primarily with its

${ }^{86}$ CJEU, Schrems v. Data Protection Commissioner, No. C-362/14 (ECLI: EU:C:2015:650), Judgment (6 October 2015).

${ }^{87}$ See next section below.

${ }^{88}$ Cf. Ambos, European Criminal Law, above n 44 at Chap. V mn. 7 ff.; Ambos and Bock 'Brexit and the European Criminal Justice System - An Introduction', above $\mathrm{n} 4$ at 4.2 .

${ }^{89}$ Cf. Ambos, European Criminal Law, above n 44 at Chap. V mn. 16 ff.; Ambos and Bock 'Brexit and the European Criminal Justice System - An Introduction', above $\mathrm{n} 4$ at 4.3 .

${ }^{90}$ For the legal framework currently in force see: Regulation 2016/794/EU of the European Parliament and of the Council on the European Union Agency for Law Enforcement Cooperation (Europol) and Replacing and Repealing Council Decisions 2009/371/JHA, 2009/934/JHA, 2009/935/JHA, 2009/936/JHA and 2009/968/ JHA, OJ EU L 135 of 24 May 2016, 53; and on Eurojust Council Decision 2002/187/ JHA Setting up Eurojust with a view to Reinforcing the Fight against Serious Crime, OJ EU L 63 of 6 March 2002,1, as amended by Council Decision 2009/426/JHA, OJ EU L 138 of 4 June 2009, 14. 
co-ordination functions. ${ }^{91}$ Brexit would come as a shock here as the UK has been instrumental in shaping the evolution and role of these bodies: two out of four of the Presidents of Eurojust thus far have come from the UK (Aled Williams and Eurojust's inaugural President, Mike Kennedy), while the current Director of Europol, Rob Wainwright, is also British. The UK has been instrumental in exporting parts of its model of intelligence-led policing into Europol and its absence as a full member from the organisation will be felt not only within Europol, but also in terms of the UK security landscape. ${ }^{92}$ As will be seen below, the UK is one of the highest contributors to EU security co-operation as regards contributions to Europol and its databases. ${ }^{93}$ In terms of participation in Eurojust activities, UK authorities organised 28 and participated in 69 Eurojust coordination meetings in 2015, and organised one and participated in seven of Eurojust's coordination centres, which facilitate the exchange of information among judicial authorities in real time and enable direct support towards the coordinated, simultaneous execution of, inter alia, arrest warrants, searches and seizures in different countries. ${ }^{94}$ Brexit will not only take away the UK's strategic leadership in the development of these EU criminal justice agencies, but will also pose a challenge vis-à-vis maintaining co-operation channels between UK authorities and the agencies. Future co-operation will again depend on the extent to which the UK will be deemed to comply with key EU law standards, including- in particular in cases involving the exchange of personal data- an assessment by EU institutions that the UK provides an adequate level of data protection. ${ }^{95}$

${ }^{91}$ On the key issues in negotiations on the future of Eurojust see Mitsilegas, $E U$ Criminal Law After Lisbon, above n 36 at Chap. 4.

${ }^{92}$ See in this context the warning of Rob Wainwright on the adverse security consequences of Brexit for the UK: Brexit would bring serious security consequences - Europol head http://uk.reuters.com/article/uk-britain-eu-europol-idUKKCN0XG 16B, last visited 19 April 2016.

93 The National Crime Agency pointed out that the UK was 'the second-largest contributor in Europe' to the Europol Information System, and that it led on 'four or five' of the 13 EMPACT [European Multidisciplinary Platform Against Criminal Threats] projects, which coordinate actions by Member States and EU organisations against threats identified by Europol in its Serious and Organised Crime Threat Assessment.'- evidence to House of Lords European Union Committee, Brexit: Future UK-EU Security Cooperation, Q 19.

${ }^{94}$ Eurojust Annual Report 2015,15-17.

${ }^{95}$ See Art. 25 of the new Europol Regulation 2016/794/EU regarding transfer of personal data to third countries and international organisations. 


\section{THE LEGAL POSITION OF THE UK AFTER BREXIT}

As seen above, the UK Government has put forward the benefits of EU criminal justice initiatives when called to justify opting back into a list of 35 third pillar measures (including the EAW and Decisions forming the legal bases for the operation of the key EU criminal justice agencies Eurojust and Europol) after the expiry of the deadline prescribed in the Lisbon Transitional Provisions Protocol. The willingness of the UK Government to continue participating in such cooperative arrangements in the post-Brexit era has been expressed in a variety of ways by Secretary of State for Exiting the EU David Davis, ${ }^{96}$ by Prime Minister Theresa May, ${ }^{97}$ and enshrined in the Government's White Paper on Brexit. ${ }^{98}$ While the political will may be present, the legal reality of the post-Brexit relationship between the $\mathrm{UK}$ and the EU in the criminal justice field is complex. There are three possible legal scenarios concerning the UK's relationship with the EU in the field of criminal justice after Brexit: the conclusion of EU-UK agreements on various aspects of criminal justice co-operation; the conclusion of bilateral agreements between the UK and individual EU member states; and, in the absence of such agreements with the EU or member states, falling back to existing Council of Europe mechanisms of co-operation.

The first scenario (EU-UK agreements) appears the most desirable in terms of ensuring legal certainty, the establishment of an EU-wide level-playing field for the UK, and operational efficiency to the extent that they have the potential to maintain the UK's position as close as possible to its current position as an EU member state. There are precedents of conclusion of agreements between the EU and third countries in the field of judicial co-operation in criminal matters (see

\footnotetext{
${ }^{96}$ According to David Davis, 'maintaining strong security co-operation we have with the EU' as one of the Government's top four overarching objectives in negotiations and future relationship with the EU ', HC Deb, 12 October 2016, col 328.

97 'I therefore want our future relationship with the European Union to include practical arrangements on matters of law enforcement and the sharing of intelligence material with our EU allies'- PM Speech, The Government's negotiating objectives for exiting the EU, 17 January 2017.

98 'As we exit, we will therefore look to negotiate the best deal we can with the EU to cooperate in the fight against crime and terrorism. We will seek a strong and close future relationship with the EU, with a focus on operational and practical crossborder cooperation'- The UK's Exit from and new partnership with the European Union, Presented to Parliament by the Prime Minister February 2017, Cm 9417.
} 
the EU agreements on surrender with Norway and Iceland), ${ }^{99}$ of conclusion of agreements on police co-operation (see the agreements with Norway and Iceland on Prüm ${ }^{100}$ ), of conclusion of agreements between EU agencies such as Europol and Eurojust with third countries, ${ }^{101}$ and of participation of third countries in EU databases such as the SIS. ${ }^{102}$ However, it should be noted that in the cases of both judicial co-operation in criminal matters and access to EU databases, close co-operation has been confined to third countries which are also full Schengen members. ${ }^{103}$ It will be more challenging for a third country maintaining its own border controls such as the UK to follow this precedent and achieve a level of co-operation which comes close to intra-EU co-operation arrangements. While co-operation arrangements in the case of EU agencies are more common, existing precedents demonstrate that there are significant limitations to the position of third countries in comparison to EU member states, most notably relating to the lack of direct access to EU databases and to non-participation in the core functions of the management bodies of these agencies, with limited say or powers to shape the future direction of these agencies.

${ }^{99}$ Council Decision on the Signing of the Agreement between the EU and the Republic of Iceland and the Kingdom of Norway on the Surrender Procedure between the Member States of the European Union and Iceland and Norway, OJ EU L 292 of 21 October 2006, 1. For the text of the Agreement see p. 2.

${ }^{100}$ Council Decision on the Signing, on Behalf of the European Union, and on the Provisional Application of Certain provisions of the Agreement between the European Union and Iceland and Norway on the Application of Certain Provisions of Council Decision 2008/615/JHA on the Stepping up of Crossborder Cooperation, Particularly in Combating Terrorism and Cross-Border Crime and Council Decision 2008/616/JHA on the Implementation of Decision 2008/615/JHA on the Stepping up of Cross-Border Cooperation, Particularly in Combating Terrorism and CrossBorder Crime, and the Annex thereto (2009/1023/JHA), OJ EU L 353 of 31 December 2009, 1.

${ }^{101}$ For lists of third state agreements concluded by Eurojust and Europol, see http://eurojust.europa.eu/about/Partners/Pages/third-states.aspx, and https://www. europol.europa.eu/partners-agreements, both accessed on 20 March 2017.

${ }^{102}$ See for instance the Agreement between the European Union, the European Community and the Swiss Confederation on the Swiss Confederation's association with the Implementation, Application and Development of the Schengen Acquis, OJ EU L 53 of 27 February 2008, 52.

${ }^{103}$ See evidence of Security Commissioner Julian King to the House of Commons Home Affairs Committee, 28.2.2017, according to which outside of non-EU Schengen countries there are no precedents for third countries locking into those information-sharing platforms (Q92). 
The conclusion of bilateral agreements between the UK and individual EU member states may serve to prioritise co-operation with key countries in areas of common interest (an example could be a simplified extradition agreement between the UK and Poland given the volume of EAWs currently being processed between authorities of these two EU member states). However, the conclusion of bilateral agreements will not grant the UK facilitated co-operation arrangements across the EU and from an operational perspective will not guarantee, even in cases where bilateral agreements are actually concluded, that UK requests for co-operation will be treated by EU partners with an equal priority status in comparison of requests of EU member states under EU law mechanisms such as the EAW and the EIO. Last, but not least, a fall-back to bilateral agreements may mean that existing innovations in judicial co-operation under EU law (such as the judicialisation of and speed in judicial co-operation and innovations in the field of extradition such as the effective abolition of the political offence exception, the abolition of the requirement to verify dual criminality for a wide range of criminal conduct and the abolition of the power of EU member states not to extradite their own nationals) may cease to apply rendering judicial co-operation slower and more cumbersome. The same considerations apply to the third scenario, of the UK falling back to existing CoE agreements such as the agreements on Extradition and Mutual Legal Assistance in its relations with EU member states. These agreements have been superseded in terms of innovation and in terms of their intra-EU applicability by EU criminal law instruments and they cover limited areas of EU criminal justice co-operation.

Whichever of these broad scenarios materialises after Brexit, it is clear that the UK must comply with EU law if it wishes to pursue meaningful co-operation in the field of criminal justice and security with the EU and its member states. This is obviously the case in the first scenario, namely the conclusion of agreements with the EU. EU external action must be consistent with EU internal action, with the Treaty on the European Union (TEU) affirming that the Union must not only respect, but also promote its internal values in its external action. ${ }^{104}$ The same applies however also in the cases of UK bilateral co-operation with EU member states either under specific bilateral agreements or by falling back into existing CoE instruments, as EU member states are under the duty to comply with EU law in their

${ }^{104}$ For an analysis, see V Mitsilegas, 'Transatlantic Counter-Terrorism Cooperation After Lisbon' (2010) 3 EUCRIM 111. 
external relations with third states, especially in cases where the EU has acted internally (this is the case in particular with major cooperation instruments such as the EAW and the EIO). The role of the CJEU is key in this context. In the current models of co-operation with third states, third countries are not subject directly to the Court's jurisdiction and dispute resolution mechanisms have been devised. ${ }^{105}$ However, the CJEU remains competent to monitor the legality of such agreements under EU law and its case-law must be taken into account in defining and complying with EU acquis which forms the benchmark for EU external relations and co-operation between EU and third countries.

The need to respect requirements of the EU internal acquis in EU external action in the field of criminal justice has been confirmed recently by the CJEU in an extradition case where the Court found that extradition to a third state must be consistent with fundamental rights standards established by the Court in relation to the internal EU acquis on the EAW. ${ }^{106}$ The requirement to comply with EU law has been even more visible in the field of exchange of personal data and data protection. Co-operation of third countries with the EU must be based on the adoption of an EU adequacy decision confirming that the UK offers an adequate level of data protection in the eyes of the EU. ${ }^{107}$ In the case of Schrems, which concerned the EUUS safe harbour agreement, the CJEU confirmed that adequacy in this context means that the system of the third country must be 'essentially equivalent' to the EU system and that any finding of

${ }^{105}$ See the Agreement on Surrender with Norway and Iceland, above n 99; Art. 36 on dispute settlement and Art. 37 on the role of the CJEU. According to Art. 37, 'in order to achieve the objective of arriving at as uniform application and interpretation as possible of the provisions of this Agreement, must keep under constant review the development of the case law of the Court of Justice of the EC, as well as the development of the case law of the competent courts of Iceland and Norway relating to these provisions and to those of similar surrender instruments.'.

${ }^{106}$ CJEU, Aleksei Petruhhin v. Latvijas Republikas Generālprokuratura, No. C-182/15 (ECLI:EU:C:2016:630), Judgment (6 September 2016).

${ }^{107}$ See Art. 35 and 36 of the Data Protection Directive - Directive 2016/680/EU of the European Parliament and of the Council on the Protection of Natural Persons with Regard to the Processing of Personal Data by Competent Authorities for the Purposes of the Prevention, Investigation, Detection or Prosecution of Criminal Offences or the Execution of Criminal Penalties, and on the Free Movement of Such Data, and Repealing Council Framework Decision 2008/977/JHA, OJ EU L 119 of 4 May 2016, 89. 
adequacy must be subject to regular re-assessment and monitoring. ${ }^{108}$ In a consistent line of case-law, the CJEU has affirmed that the bulk collection of personal data on an indiscriminate basis is contrary to EU law. ${ }^{109}$ The current approach of the UK Government regarding the extensive collection, sharing and transfer of personal data for security purposes sits ill at ease with EU law as interpreted by the CJEU. This has been confirmed by the Court in the recent case of Watson, where UK law on data retention was found to fall foul of EU law. ${ }^{110}$

It becomes thus obvious that, if the UK wishes to continue cooperating with the EU and its member states, it will have to reassure its partners that its legal and human rights system offers a level of protection which is acceptable under EU law. While the UK may not be directly subject to the jurisdiction of the Luxembourg Court, the case-law of the latter will play a key part in determining what the EU requirements will be in this context. Meeting EU law requirements by the UK will be subject to ongoing monitoring by EU institutions including the European Commission in order to ensure that equivalence remains, and the UK will have to adjust its internal legislation to follow developments in EU law in order to maintain any ensuing co-operation arrangements. Importantly, the UK must accept the EU acquis as a whole, emanating from an increasingly interdependent EU area of criminal justice - to take an example, the EU acquis on the EAW will take also into account EU legislation and case-law on the rights of the defence in criminal proceedings, an area where the UK has currently partially opted out from. Brexit will thus bring with it the paradox that the UK will no longer be able to maintain, outside

${ }^{108}$ In the case of Schrems v. Data Protection Commissioner, No. C-362/14, above n 86 at para. 73, the CJEU found that the term 'adequate level of protection' must be understood as requiring the third country in fact to ensure, by reason of its domestic law or its international commitments, a level of protection of fundamental rights and freedoms that is essentially equivalent to that guaranteed within the European Union.

${ }^{109}$ CJEU, Digital Rights Ireland Ltd v. Minister for Communications, Marine and Natural Resources and Others and Kärntner Landesregierung and Others, No. C-293/12 and C-594/12, above n 85; Schrems v. Data Protection Commissioner, No. C-362/14, above n 86; CJEU, Tele2 Sverige AB v. Post- och telestyrelsen and Secretary of State for the Home Department v. Tom Watson and Others, No. C-203/15 and C-698/15 (ECLI:EU:C:2016:970), Judgment (21 December 2016).

${ }^{110}$ CJEU, Tele2 Sverige AB v. Post- och telestyrelsen and Secretary of State for the Home Department v. Tom Watson and Others, No. C-203/15 and C-698/15, above n 109. 
the EU, the 'pick-and-choose approach' to EU criminal law it is currently enjoying. It will be take it or leave it in terms of accepting the EU acquis if the UK wishes to maintain meaningful co-operation with the EU and its member states post-Brexit.

\section{EUROPEAN CRIMINAL LAW WITHOUT THE UK}

The article thus far has considered primarily the implications for Brexit as regards the position of the UK vis-à-vis the EU and its Member States. This section will take a different perspective, and consider the contribution of the UK to EU criminal law and thus contemplate the future of EU criminal justice co-operation after Brexit. The contribution of the UK to EU criminal law can be distinguished in four different levels: the operational level, the strategic level, the level of legislation, and the level of implementation. At the operational level, it has been well-documented that the UK is one of the highest contributors to EU security co-operation as regards contributions to Europol and its databases ${ }^{111}$ and to the Schengen Information System. ${ }^{112}$ According to the UK government, the UK uses Europol more than any other country. ${ }^{113}$ Non-participation of the UK in these EU mechanisms post-Brexit may prove costly for the UK in security terms, but may also have a detrimental effect in the operational capacity of EU agencies in the field of criminal justice and their ability to assist member states in the fight against serious and transnational crime.

The second level of contribution of the UK to EU criminal law is in terms of strategy. As has been pointed out by the House of Lords EU Committee, the UK has been a leading protagonist in driving and shaping the nature and direction of cooperation on police and

${ }^{111}$ The National Crime Agency pointed out that the UK was 'the second-largest contributor in Europe' to the Europol Information System, and that it led on 'four or five' of the 13 EMPACT [European Multidisciplinary Platform Against Criminal Threats] projects, which coordinate actions by Member States and EU organisations against threats identified by Europol in its Serious and Organised Crime Threat Assessment.'- evidence to House of Lords European Union Committee, Brexit: Future UK-EU Security Cooperation, Q 19.

${ }^{112}$ According to Security Commissioner Julian King, the UK has over 160,000 alerts on SIS II platform- evidence to Home Affairs Committee, ibid, Q86.

${ }^{113}$ HM Government, The UK's cooperation with the EU on justice and home affairs, and on foreign policy and security issues, 9 May 2016, para 1.16. 
security matters. ${ }^{114}$ A recent example of the UK pushing for further EU action in the field of security is calls for the adoption of an EU PNR system, ${ }^{115}$ while the UK has been instrumental in securing the adoption of the - controversial and now annulled by the CJEU ${ }^{116}$ data retention Directive. These examples demonstrate the - at times uncritical - promotion of a security agenda at EU level by the UK, an agenda which may clash with key EU imperatives including the protection of fundamental rights. The UK has also assumed a leading role in furthering European integration while trying to stave off integration attempts which were deemed to challenge unduly state sovereignty in criminal matters. A key example in this context has been the UK's leadership in securing the application of the principle of mutual recognition in the field of criminal law, an idea which was put forward by the then UK Home Secretary Jack Straw at the Cardiff European Council in 1998. ${ }^{117}$ Put forward partly to forestall attempts for supranational European integration deemed to threaten state sovereignty in criminal matters and to ensure a 'lighter-touch' integration whereby co-operation between national authorities is encouraged but without member states having to change their laws, the application of the principle of mutual recognition has provided momentum and drive for the development of European integration in the contested field of criminal law.

The strategic input of the UK is also linked with the considerable impact that UK officials have made in the development, drafting and implementation of secondary EU criminal law. In addition to UK Government officials who have participated actively in the negotiations of EU instruments in Brussels, ${ }^{118}$ mention should be made here of UK officials in EU institutions, who have made significant contributions to the development of EU criminal law. There are two

${ }^{114}$ House of Lords European Union Committee, Brexit: future UK-EU security and police cooperation, above $\mathrm{n} 65$ at para. 27.

115 'The UK Governemnt said in May 2016 that it had made consistent calls for EU PNR legislation', House of Lords, ibid at para 100.

116 CJEU, Digital Rights Ireland Ltd v. Minister for Communications, Marine and Natural Resources and Others and Kärntner Landesregierung and Others, No. C-293/12 and C-594/12, above n 85.

${ }^{117}$ For the background, see Mitsilegas, EU Criminal Law, above n 42 at Chap. 3.

${ }^{118}$ For an account of negotiating practices in the Council in the post-Lisbon codecision era by a British official see H Nowell-Smith, 'Behind the Scenes in the Negotiation of EU Criminal Justice Legislation' (2012) 3 New Journal of European Criminal Law 381. 
examples worth mentioning in this context. The first example is Caroline Morgan, a Commission official which has been instrumental in drafting and generating momentum for the adoption of the first ever EU criminal law instrument focusing on human rights, the FD tabled by the Commission in 2004 on procedural rights in criminal proceedings. While the FD was not adopted, it paved the way for the subsequent momentum which has resulted in the post-Lisbon adoption of a series of sectoral Directives on procedural rights, measures which will have a transformative effect on the development of European integration in criminal matters and the relationship between the individual and the state in Europe's area of criminal justice. ${ }^{119}$ The second example is at the level of the interpretation of EU criminal law, and consists of the contribution of Advocate General ("AG") Sharpston towards the shaping of EU criminal law. Even in cases where AG Sharpston's Opinions have not been fully adopted by the CJEU, they have presented new ways of thinking about key issues in the field of European criminal justice and the balance of interests therein. Her Opinion in $R a d u^{120}$ provided the first judicial analysis of the potential application of the principle of proportionality in the context of mutual recognition in criminal matters. Both examples demonstrate the dynamic contribution that British jurists have made and can make in the evolution of EU criminal law- such contributions will be missed post-Brexit. Another UK contribution which may be missed lies at the level of implementation of EU criminal law at national level. Here, the high level of both advocacy and parliamentary scrutiny within the UK has resulted in significant contributions in reshaping the relationship between criminal law and fundamental rights at the domestic level. A most recent example has been the amendment of the UK Extradition Act 2003 to include an express ground to refuse to execute a EAW on proportionality grounds. ${ }^{121}$ While this ground for refusal arguably goes beyond current EU law in the field, the emphasis on the limits of mutual

${ }^{119}$ See V Mitsilegas, 'Legislating for Human Rights After Lisbon: The Transformative Effect of EU Measures on Procedural Rights in Criminal Proceedings', in M Fletcher, E Herlin-Karnell and C Matera (eds), The European Union as an Area of Freedom, Security and Justice (London, Routledge, 2017) 201.

${ }^{120}$ CJEU, Ministerul Public - Parchetul de pe lângă Curtea de Apel Constanta v. Ciprian Vasile Radu, No. C-396/11 (ECLI:EU:C:2012:648), Opinion of Advocate General (18 October 2012).

${ }^{121}$ Section 157 of the Anti-Social Behaviour, Crime and Policing Act 2014 has amended Section 21A of the Extradition Act 2003 to treat lack of proportionality as a ground for refusal to execute a EAW (section 21A(1)(b)). 
recognition on the grounds of protecting human rights and on proportionality grounds which has been debated in the UK for a long time ${ }^{122}$ has been recently mirrored in EU law both in secondary law instruments such as the EIO Directive and in the Court's recent caselaw on the EAW. All these examples demonstrate the varied and multi-faceted contribution that the UK has made in the development of the EU criminal justice acquis. While the impact of UK Governmental policy has been to privilege, at times uncritically, an EU security agenda, the impact of other actors, including officials, judges, advocates and parliamentarians in Brussels and London have contributed in shaping EU law in different ways, including by placing emphasis on the protection of fundamental rights in EU criminal law. There is further potential for such contribution since December 2014, as the expiry of the Transitional Provisions Protocol deadline has granted the right to UK courts to refer third pillar cases to Luxembourg under the preliminary reference procedure. However, such a right may be short-lived in the run up to Brexit.

\section{CONCLUSION: THE TRIPLE PARADOX OF BREXIT}

The ongoing relationship between the UK and the EU in the field of criminal law and its reconfiguration as we are heading towards the post-Brexit era is characterised by a high level of constitutional complexity and is underpinned by a triple paradox. In the first place, the UK's current position as an EU member state is marked by the tension between maintaining (or being seen as able to maintain) national sovereignty in the field of criminal law while at the same time seeking maximum co-operation with EU member states and EU agencies in the field of security. The collateral damage in this tension lies in the protection of fundamental rights, easily sacrificed in the various UK opt-outs from post-Lisbon European criminal law. The dynamic evolution of EU law in the field however leads to a second paradox in the post-Brexit era: the UK's willingness to continue to reap the security benefits of EU co-operation after Brexit can be accommodated only if the UK complies fully with the EU acquis, including the acquis on the protection of fundamental rights, part of which it currently is at liberty to disregard under its 'opt-outs' as an EU member state. Brexit will thus bring the UK in the paradoxical

${ }^{122}$ For an overview of fundamental rights concerns arising from the operation of the EAW in the UK, see Joint Committee on Human Rights, The Human Rights Implications of UK Extradition Policy, Fifteenth Report, session 2010-2012, 40-43. 
position of having to accept more EU law than it currently does as an EU member state. The post-Brexit era will also bring a third paradox, this time for the EU. Although not by its own will, the EU will develop criminal law with the UK's influence being less marked (although probably not lost altogether). It remains to be seen whether this will have an impact on the content and direction of European criminal law in the future, but it will most certainly have a negative impact on quality control and scrutiny of European criminal law preadoption and post-implementation by UK institutions and officials in the UK and Brussels. What appears even more paradoxical in this context is that it appears that the UK's current 'pick-and-choose' approach in sensitive politically matters appears to be slowly becoming the norm not only in European criminal law (see for example the imminent launch of a EPPO a-la-carte), but also regarding European integration more broadly - with 60th birthday celebrations for the EU bringing into the fore increasingly the prospect of a 'multi-speed Europe.'

\section{OPEN ACCESS}

This article is distributed under the terms of the Creative Commons Attribution 4.0 International License (http://creativecommons.org/ licenses/by/4.0/), which permits unrestricted use, distribution, and reproduction in any medium, provided you give appropriate credit to the original author(s) and the source, provide a link to the Creative Commons license, and indicate if changes were made. 